Bangladesh J. Bot. 37(1): 43-48, 2008 (June)

\title{
ALGAL FLORA OF MADHABKUNDA WATERFALL AREA IN MAULVI BAZAR, BANGLADESH. III. NEW RECORDS OF BLUE-GREENS AND GREENS
}

\author{
Abdul AzIz \\ Department of Botany, University of Dhaka, Dhaka-1000, Bangladesh
}

Key words: Blue-green algae, Cyanobacteria, Green algae, Waterfall, Bangladesh

\begin{abstract}
Examination of samples from Madhabkunda waterfall area at Maulvi Bazar, Bangladesh revealed the presence of Aphanocapsa montana Cramer, Oscillatoria acuiformis Skuja, Oscillatoria redeckii Van Goor, Gloeotrichia natans (Hedwig) Rabenh., Nostochopsis lobatus Wood em Geitler, Schizochlamys gelatinosa A. Br. and Kirchneriella dianae (Bohl.) Coms var. dianae Bohl., Oscillatoria redeckii Van Goor is a new records for this Subcontinent. Aphanocapsa montana Cramer, Oscillatoria acuiformis Skuja, Nostochopsis lobatus Wood em Geitler and Kirchneriella dianae (Bohl.) Coms var. dianae Bohl. are new records for Bangladesh.
\end{abstract}

\section{Introduction}

Aziz and Yasmin (1997a-b) recorded 22 taxa of blue-greens, 12 greens, 10 diatoms and a red alga from Madhabkunda waterfall area, in the district of Maulvi Bazar, Bangladesh. Re-examination of some samples collected in 1995 revealed the presence of more algae belonging to Cyanobacteria and Chlorophyta, which are described and illustrated in the present account.

\section{Materials and Methods}

Materials were collected from Madhabkunda waterfall area, in the district of Maulvi Bazar, Bangladesh. The details of collections are given elsewhere (Aziz and Yasmin 1997a-b).

\section{Results and Discussion}

\section{Class: Cyanophyceae; Order Chroococcales; Family: Chroococcaceae Genus: Aphanocapsa Nägeli}

\section{Aphanocapsa montana Cramer}

(Figs. 1-2)

(Desikachary 1959, 135, pl. 20, fig. 8)

Colony small, elliptical to no definite shape, mucilage boundary not discernible in water mount, consisting of more than 150 cells of extremely variable size, 2.00-4.00 $\mu \mathrm{m}$ diameter but all are distinctly round. Individual cells when young (small ones) are without sheath but when old (large ones) are with distinct sheath, all cells are round, a feature like Microcystis viridis (A. Br.) Lemm. (Desikachary 1959, 87, pl. 18, figs. 1-6). Cell interior very homogenous (non-granular) and light blue-green in colour. It is uncertain if the small non-sheathed cells are nonnospores or not.

Distribution: Reported from U.P. and Calcutta, India on submerged objects, species of Pithophora and tree trunks (Desikachary 1959). For Bangladesh, this is a new record and was found along with filamentous green algae on the margin of a stream originating from the Madhabkunda waterfall. 

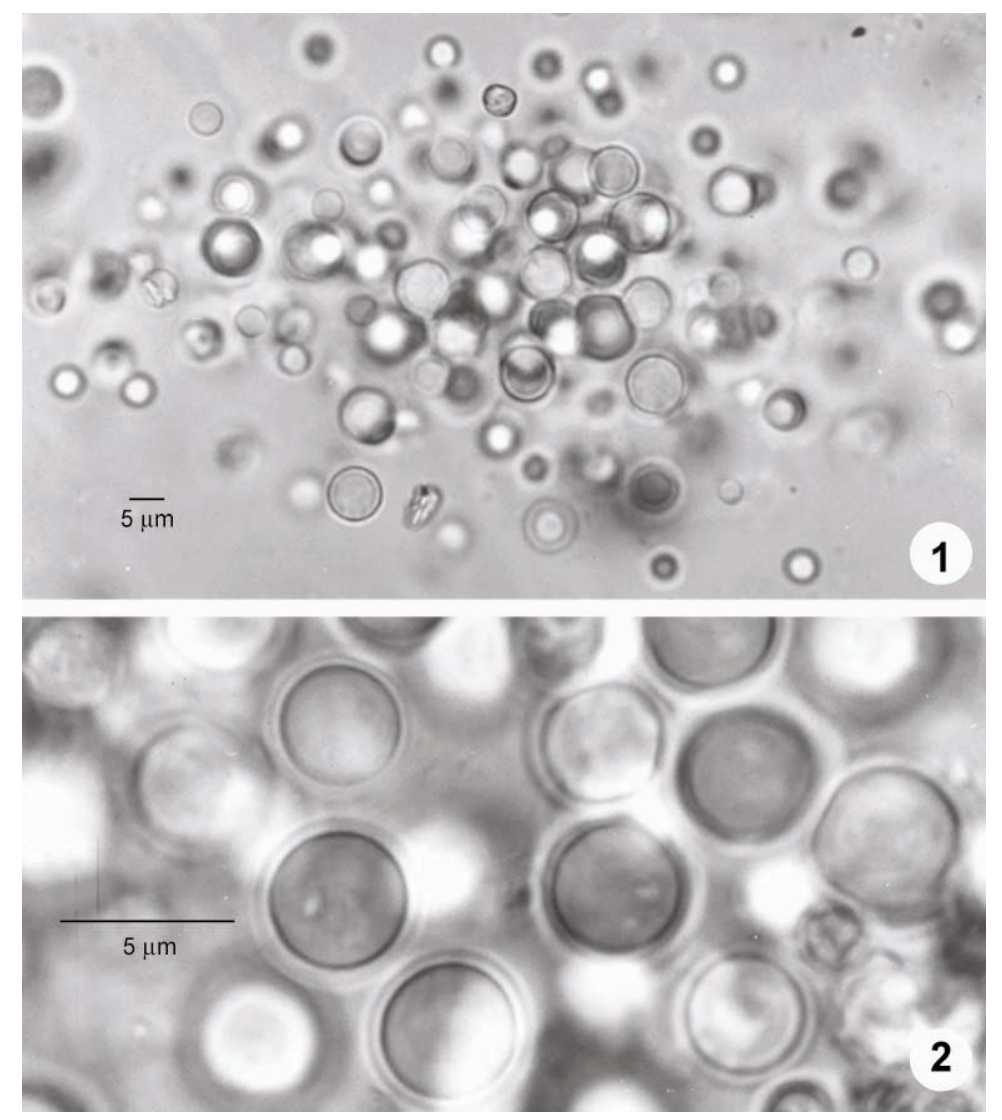

Figs. 1-2. Aphanocapsa montana, whole colony (1) and a part highly enlarged (2).

\section{Order: Oscillatoriales; Fam.: Oscillatoriaceae \\ Genus: Oscillatoria Vaucher}

2. Oscillatoria acuiformis Skuja

(Fig. 3)

(Starmach 1966, 353, figs. 518)

Trichomes are very narrow, coiled and gradually narrowed apically with pointed tip cell. All cells are with two large granules, cross walls not distinct; 5.00-7.00 $\mu \mathrm{m}$ broad and 7.00-20.00 $\mu \mathrm{m}$ long.

Distribution: Skuja (1949) first reported the taxon from Burma, while Starmach (1966) recorded it from Poland. For Bangladesh, this is a new record.

\section{Oscillatoria redeckii Van Goor}

(Fig. 4)

(Starmach 1966, 341, figs. 488-489)

Trichomes are very narrow and uniformly broad although with blunt tips. Cells 4-6 times longer than broad, 5.00-8.00 $\mu \mathrm{m}$ broad, $25-30 \mu \mathrm{m}$ long with two large granules one at each end. Cells at many points are separated from each other in the prepared slides.

Distribution: Not reported so far from this Sub-Continent. Recorded from Poland (Starmach 1966). For Bangladesh, this is a new record. 


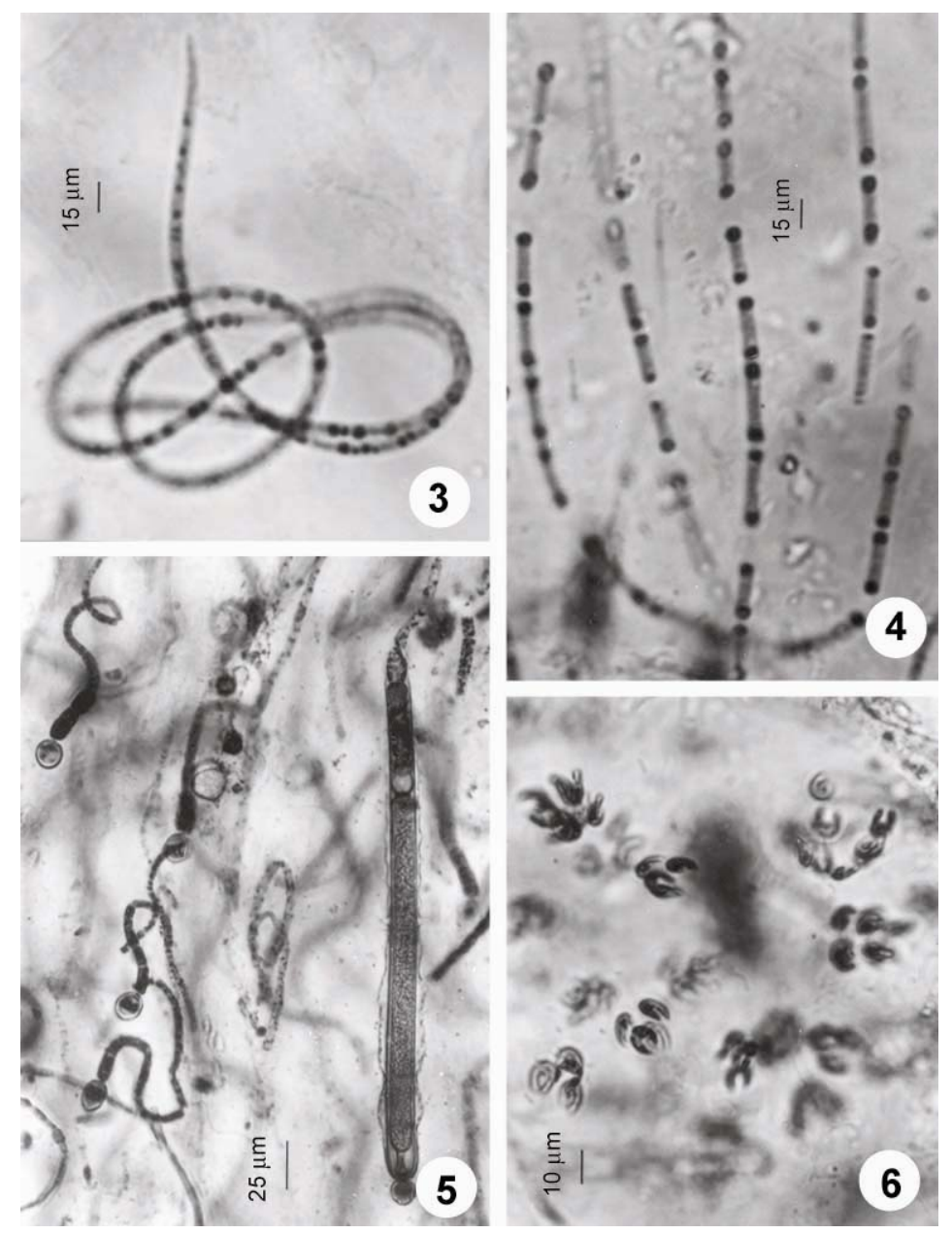

Figs. 3-6: 3. Oscillatoria acuiformis. 4. Oscillatoria redeckii. 5. Gloeotrichia natans, a part of a colony with filaments of various ages. 6. Kirchneriella dianae var. dianae.

\section{Order: Rivulariales; Family: Rivulariaceae \\ Genus: Gloeotrichia J. Ag.}

4. Gloeotrichia natans (Hedwig) Rabenh.

(Fig. 5)

(Starmach 1966, 567-570, Fig. 862g)

Thallus amorphous and mucilaginous, consisting of loosely arranged filaments of various ages. Trichomes are tapered, 6-8 $\mu \mathrm{m}$ broad near the heterocyst. Heterocysts are spherical to ellipsoidal; akinete cylindrical and very long with thick wall and surrounded by wavy to constricted, narrowly saccate, $15-25 \mu \mathrm{m}$ wide sheath. The long akinete next to heterocyst is followed by another heterocyst and a shorter akinete.

Distribution: A common tapered cyanobacterium of world-wide distribution. In Bangladesh, the alga grows abundantly on hydrophytes and in late flood period colonies float as big amorphous masses (Aziz and Ahmed 1991). The alga has been reported from other habitats of Bangladesh (Islam and Uddin 1973). 


\section{Order: Stigonematales; Fam.: Stigonemataceae Genus: Nostochopsis Wood em Geitler}

5. Nostochopsis lobatus Wood em Geitler

(Figs. 7-12)

(Syn: Mastigochladopsis jogensis Iyenger et Desikachary)

(Desikachary 1959, 570-572, pl. 120, Figs. 1-8; Starmach 1966, 705-709, Fig. 1034)

Colonies spherical and semisolid when young, to irregularly lobed and hollow-like central part when mature and attained a diameter of about $2.00 \mathrm{~cm}$. It is composed of truly branched radiating filaments; branching rich on the peripheral region of the filaments. Filaments of main axis and branches are uniseriate. In almost all cases branching is unilateral giving the appearance of some species of Hapalosiphon. Branching broadly stretched upward by a short bend and with its end being parallel to the main filament. Cells of the main axis are cylindrical to barrel-shaped, 4.00-5.00 (8.00) $\mu \mathrm{m}$ broad, up to $18.00 \mu \mathrm{m}$ long. Trichomes gradually narrowed up to the tip, appearing almost hair-like. Heterocysts are lateral and pedicillate on 1-3 celled branches; spherical in shape, $7.00-9.00 \mu \mathrm{m}$ broad.

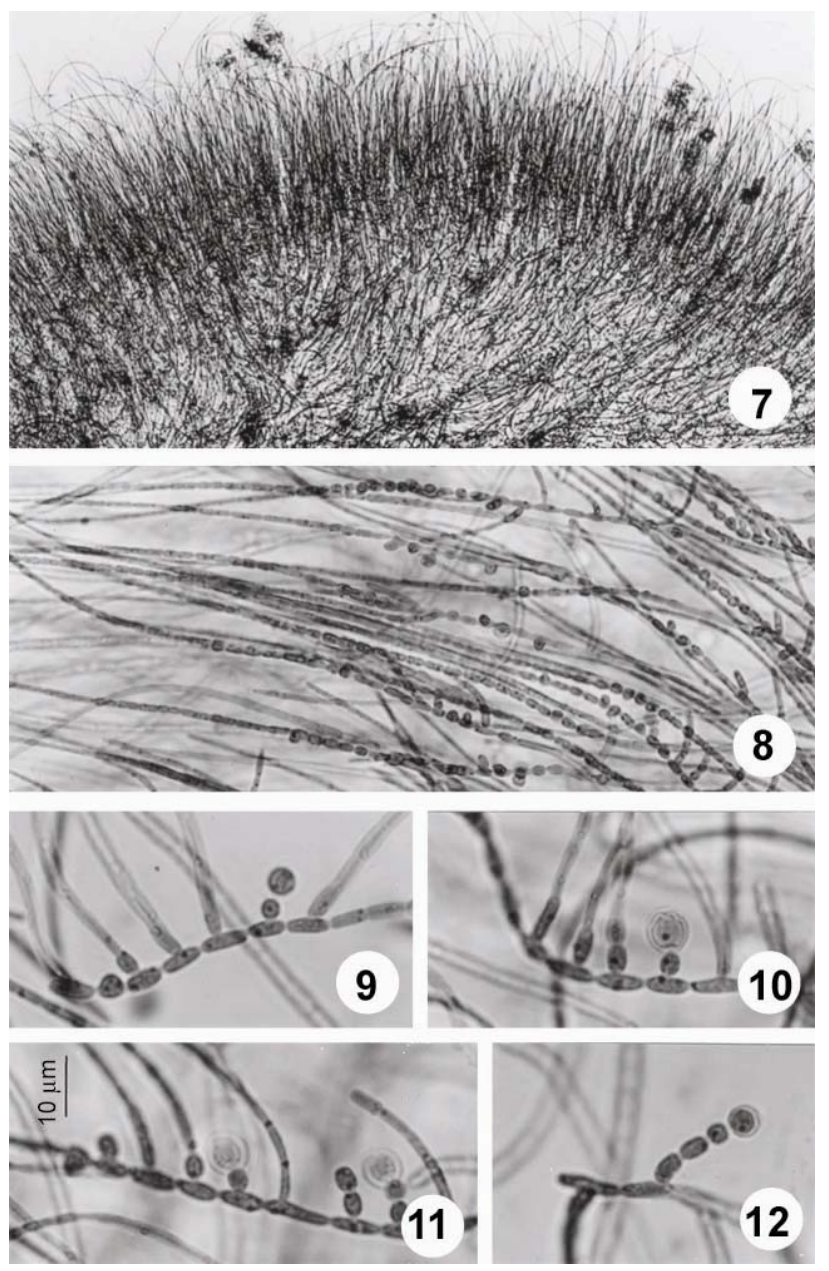

Figs. 7-12. Nostochopsis lobatus, peripheral part of a colony (7), branching pattern of filaments near the periphery (8), stalked heterocysts (9-12). 
Mastigochladopsis jogensis Iyenger et Desikachary (Desikachary 1959) has been considered as a synonym of Nostochopsis lobatus Wood em Geitler because of the fact that the reverse ' $\mathrm{V}$ 'shaped branching is not a stable character and could be formed at late stage of growth in cultures of stigonematalean algae (Begum et al. 1994) and that other features are similar to Nostochopsis lobatus Wood em Geitler.

Distribution and habitat: The alga grows in standing or flowing freshwaters as attached or free-floating structures. It has been reported from various parts of the world from ponds, streams, canals, lakes and rivers (Desikachary 1959). In Bangladesh the alga was found on seeping sandstones of a cave in Madhabkunda waterfall area. For Bangladesh, this is a new record.

\section{Class: Chlorophyceae; Order: Chlorococcales; Fam.: Chlorococcaceae Genus: Schizochlamys A. Br.}

\section{Schizochlamys gelatinosa $\mathrm{A}$. $\mathrm{Br}$.}

(Figs. 13-16)

(Prescott 1968, 55, Fig. 21)

Thallus colonial, forming amorphous gelatinous mass, consisting of many spheroidal, anteroposteriorly slightly flattened cells (Fig. 13). Each cell with 4-8 pseudocilia, and a wide gap between the massive cup-shaped chloroplast and the cell wall. Cells divide into new ones and pieces of parent cell wall remain about the daughter cells (Figs. 14-15). The alga enters into the palmelloid-stage where cells are distinctly rounded (Fig. 16).

Islam (1969) reported a sac-like (hollow balloon-like when young) thallus which is composed of numerous daughter cells in quadrates with fragments of parent cell wall about the quadrates. Pseudocilia were not recorded. He considered it under the species with a doubt.

Distribution: Islam (1969) reported this as a doubtful species from a ditch at Mirpur, Dhaka.
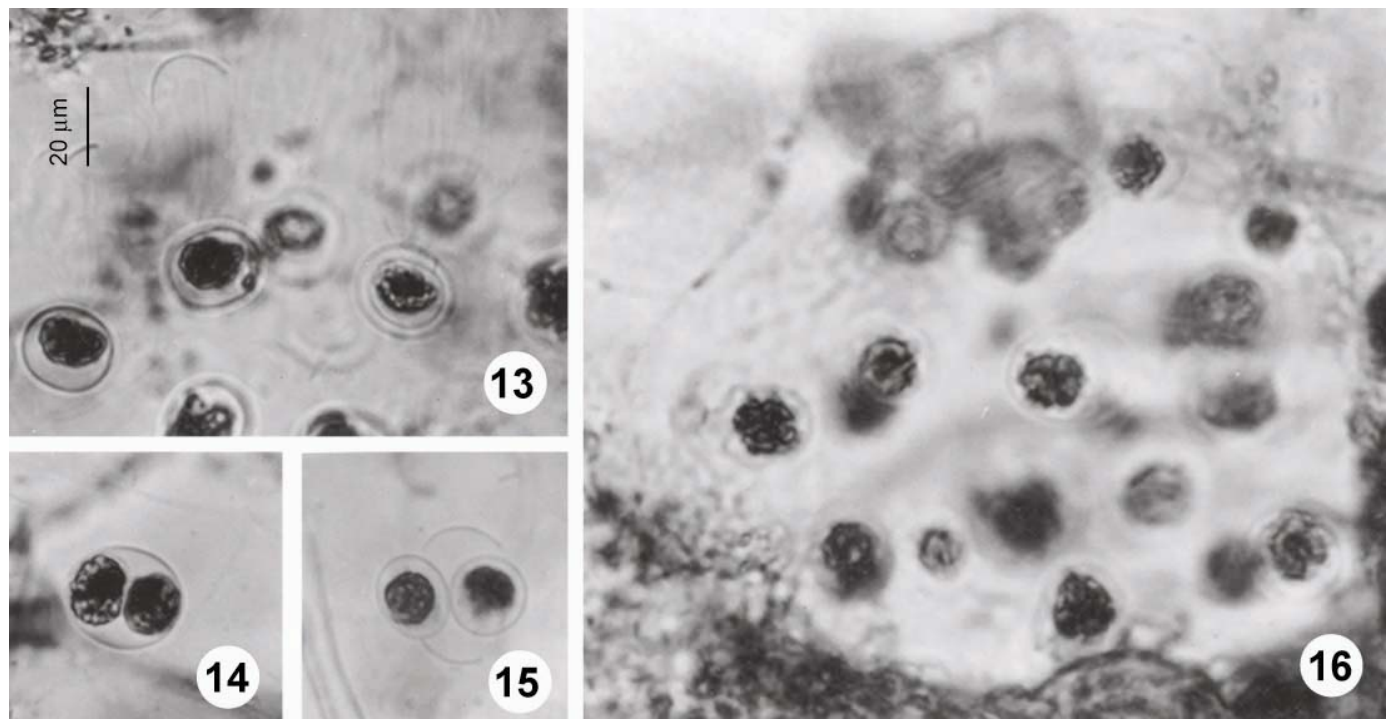

Figs. 13-16: Schizochlamys gelatinosa: a part of the colony showing cells with pseudocilia (13), a dividing cell (14), two daughter cells with fragmented parent wall (15), and a young amorphous colony (16). 


\section{Genus: Kirchneriella Schmidle}

7. Kirchneriella dianae (Bohl.) Coms var. dianae Bohl.

(Fig. 6)

(Syn.: Kirchneriella lunaris (Kirch.) Moebius)

(Huber-Pestalozzi 1983, 668, Pl. 187, fig. 1a)

Thallus colonial, up to 64 celled, microscopic; cells narrow, strongly curved with semicircular sinus, 3.3-9.9 $\mu \mathrm{m}$ long, 3.0-6.0 $\mu \mathrm{m}$ broad and live within watery mucilage forming a more or less spherical colony. Chloroplast single and cup-shaped with a pyrenoid. Each cell undergoes two divisions producing 4 daughter cells which are released in groups of four as autospores, each of which again produce 4 autospores gradually forming an amorphous colony.

Distribution: This is the first record for Bangladesh.

\section{References}

Aziz, A. and A. Ahmed. 1991. Occurrence and biomass of Gloeotrichia epiphytic on deepwater rice plants near Sonargaon, Bangladesh. Bangladesh J. Bot. 20(1): 97-100.

Aziz, A. and N. Yasmin. 1997. Algal flora of Madhabkunda waterfall area in Moulvibazar, Bangladesh. I. Blue-green and red algae. Bangladesh J. Bot. 26(1): 9-18.

Aziz, A. and N. Yasmin. 1997. Algal flora of Madhabkunda waterfall area in Moulvibazar, Bangladesh. II. Green algae and diatoms. Bangladesh J. Bot. 26(2): 177-186.

Begum, Z.N.T., R. Akhter, A.K.M. N. Islam and A. Aziz. 1994. Taxonomy of the Stigonematalean algae in culture. In: Algal Biotechnology in the Asia-Pacific Region (Phang S.M., L.Y. Kun, M.A. Borowitzka and B.A. Whitton, eds.), pp. 257-262. Univ. Malaya.

Desikachary, T.V. 1959. Cyanophyta. Indian Council of Agricultural Research, New Delhi. pp. 686.

Huber-Pestalozzi, G. 1983. Das phytoplankton des Süßwasser. Vol. 7, No. 1. Stüttgart. pp. 1044.

Islam, A.K.M. N. 1969. Some rare planktonic green algae found in East Pakistan. Pak. J. Bot. 1: 19-32.

Islam, A.K.M. N. and A. Uddin. 1973. Freshwater algae of Bangladesh. II. Cyanophyceae. Dhaka Univ. Stud. B 21(2): 127-132.

Prescott, G.W. 1968. The algae: A review. Houghton Mifflin Co., Boston. pp. 436.

Starmach, K. 1966. Cyanophyta-sinice, Glaucophyta-Glaukofity. Flora stodkowodna Polski. Tom- 2. Polska Academia Nauk, Warszawa. pp. 806.

(Manuscript received on 2 October, 2007; revised on 6 April, 2008) 